\title{
Relationship between macrofauna, mineralogy and exchangeable calcium and magnesium in Cerrado Oxisols under pasture
}

\author{
Pedro Rodolfo Siqueira Vendrame(1), Robélio Leandro Marchão(2), Osmar Rodrigues Brito(3), \\ Maria de Fátima Guimarães ${ }^{(3)}$ and Thierry Becquer ${ }^{(4)}$
}

\begin{abstract}
(1)Universidade Estadual de Londrina (UEL), Departamento de Geociências, Rodovia Celso Garcia Cid, Km 380, Caixa Postal 6.001, CEP 86051-990 Londrina, PR, Brazil. E-mail: vendrame@uel.br (2)Embrapa Cerrados, Caixa Postal 08223, CEP $73310-970$ Planaltina, DF, Brazil. E-mail: robelio.leandro@cpac.embrapa.br ${ }^{(3)} \mathrm{UEL}$, Departamento de Agronomia. E-mail: osmar@uel.br, mfatima@uel.br (4)Institut de Recherche pour le Développement, Unité Mixte de Recherche 210, SupAgro, 2 Place Viala, Bâtiment 12, 34060 Montpellier Cedex 2, France. E-mail: thierry.becquer@ird.fr
\end{abstract}

\begin{abstract}
The objective of this work was to assess the relationship between macrofauna, mineralogy and exchangeable calcium and magnesium in Cerrado Oxisols under pasture. Twelve collection points were chosen in the Distrito Federal and in Formosa municipality, Goiás state, Brazil, representing four soil groups with varied levels of calcium + magnesium and kaolinite/(kaolinite + gibbsite) ratios. Soil macrofauna was collected in triplicate at each collection point, and identified at the level of taxonomic groups. Macrofauna density showed correlation with contents of kaolinite, gibbsite and exchangeable $\mathrm{Ca}+\mathrm{Mg}$ in the soils. Mineralogy and exchangeable $\mathrm{Ca}+\mathrm{Mg}$ had significant effects on taxonomic groups and relative density of soil macrofauna. The termites (Isoptera) were more abundant in soils with low exchangeable $\mathrm{Ca}+\mathrm{Mg}$; earthworms (Oligochaeta), in soils with high levels of kaolinite; and Hemiptera and Coleoptera larvae were more abundant in gibbsitic soils with higher contents of total carbon.
\end{abstract}

Index terms: gibbsite, kaolinite, soil fauna, soil fertility, total carbon.

\section{Relações entre macrofauna, mineralogia, cálcio e magnésio trocáveis em Latossolos do Cerrado sob pastagem}

\begin{abstract}
Resumo - O objetivo deste trabalho foi avaliar as relações entre a macrofauna, a mineralogia e os teores de cálcio e magnésio, em latossolos do Cerrado sob pastagem. Doze pontos de coleta foram escolhidos no Distrito Federal e no Município de Formosa, GO, e representaram quatro grupos de solo com variados teores de cálcio + magnésio e razões caulinita/(caulinita + gibsita). A macrofauna do solo foi coletada em triplicata, em cada ponto, e identificada quanto ao grupo taxonômico. A densidade da macrofauna foi relacionada aos teores de caulinita, gibsita e $\mathrm{Ca}+\mathrm{Mg}$ trocáveis. Houve efeito significativo da mineralogia e dos teores de $\mathrm{Ca}+\mathrm{Mg}$ trocáveis sobre os grupos taxonômicos e sobre a densidade relativa da macrofauna edáfica. Verificou-se maior densidade de Isoptera nos solos com baixos teores de $\mathrm{Ca}+\mathrm{Mg}$, de Oligochaeta nos solos cauliníticos, e maior densidade de Hemiptera e larvas de Coleoptera nos solos gibsiticos e com maiores teores de carbono total.
\end{abstract}

Termos para indexação: gibbsita, caulinita, fauna do solo, fertilidade do solo, carbono total.

\section{Introduction}

The Cerrado region, the second largest biome in Brazil, occupies an area of 204 million ha. Native and cultivated pastures extend over an estimated area of 117 million ha, of which 54 million ha are cultivated pastures, according to Sano et al. (2008). The majority of the soils of this region is highly weathered, and characterized by low cation exchange capacity, low base saturation and high aluminum saturation. These characteristics are particularly valid for the Oxisols or "Latossolos", according to the Brazilian soil classification (Santos et al., 2006), there soils cover almost half of the region's total area (Reatto \& Martins, 2005). The clay fraction of these Oxisols is predominantly composed of kaolinite, gibbsite, goethite and hematite, in descending order of quantity (Motta et al., 2002).

In tropical soils, notably in the Cerrado biome, macrofauna plays an important role in maintaining ecosystem services (Lavelle et al., 2006), as it is intimately associated with the processes of organic material decomposition and nutrient cycling (Blanchart et al., 2006), and affects the physical, chemical and 
biological attributes of the soil (Lavelle \& Spain, 2001). Diverse groups of macrofauna, considered "soil engineers" (worms, termites and ants), build structures with diverse physical and chemical characteristics, and are able to influence the availability of nutrients for plants (Decaëns, 2000).

Thereare still relatively few studies on the macrofauna abundance and diversity in Cerrado pastures. Some authors, such as Benito et al. (2004), Silva et al. (2006) and Marchão (2007) examined transformations in the population of soil macrofauna after the conversion of native Cerrado into agropastoral systems. After these, there were no published studies on the relationship between fertility and macrofauna, nor on the effect of clay fraction mineralogy on soil macrofauna.

This work was based on the premise that soil biodiversity, notably that of invertebrate macrofauna, is intimately linked to chemical and physical attributes and to soil management, and cannot be studied separately. Therefore, we aimed to analyze the relationship between diversity and abundance of macrofauna and mineralogy (kaolinite and gibbsite) and levels of exchangeable $\mathrm{Ca}+\mathrm{Mg}$, in Oxisols under pasture in the Cerrado biome.

\section{Materials and Methods}

In order to select the study areas, geological and pedological maps of the region were consulted. Based on cartographic analysis, areas with a predominance of Oxisols, were selected. The chosen areas are located in the Distrito Federal, and in the municipality of Formosa, Goiás, Brazil $\left(15^{\circ} 30^{\prime} \mathrm{S}\right.$ to $16^{\circ} 10^{\prime} \mathrm{S}$, and $47^{\circ} 22 \mathrm{~W}$ to $48^{\circ} 11^{\prime} \mathrm{W}$, respectively), at altitudes ranging from $850 \mathrm{~m}$ to $1,200 \mathrm{~m}$ a.s.l.
To select the specific points for soil macrofauna sampling, composite soil samples were collected to determine chemical properties. First, exchangeable $\mathrm{Ca}+\mathrm{Mg}$ was determined using $\mathrm{KCl} 1 \mathrm{~mol} \mathrm{~L}^{-1}$ (Claessen, 1997). Then, samples selected for their $\mathrm{Ca}+\mathrm{Mg}$ contents were analyzed for their kaolinite and gibbsite content by thermogravimetric analysis (ATG), using a TGA-50 Shimadzu equipment (Melo et al., 2001), in order to calculate the kaolinite/(kaolinite + gibbsite) ratios $\left(\mathrm{R}_{\mathrm{KGb}}\right)$. After these procedure, 12 collection points (plots) were chosen for macrofauna sampling, representing four soil groups (GI-GIV) of different characteristics: the soils belonging to GI and GII had low levels of exchangeable $\mathrm{Ca}+\mathrm{Mg}\left(<1.0 \mathrm{cmol}_{\mathrm{c}} \mathrm{kg}^{-1}\right)$, while soils in GIII and GIV had higher levels (2.1 to $\left.4.0 \mathrm{cmol}_{\mathrm{c}} \mathrm{kg}^{-1}\right)$. In terms of mineralogy, groups I and III had low $\mathrm{R}_{\mathrm{KGb}}(0.45$ to 0.60$)$, while groups II and IV had high $\mathrm{R}_{\mathrm{KGb}}(0.75$ to 0.90$)$ (Table 1 , Figure 1$)$. In addition, the total levels of carbon (C) and nitrogen (N) were determined using a Perkin-Elmer CHNS 2400 element analyzer. At the moment of sampling, all plots were occupied by cultivated pastures. The collection points were geo referenced using GPS equipment. The collection point locations and the results of chemical and mineralogical soil analysis for each group are shown in Table 1.

Collection of soil macrofauna took place on the first half of February 2007. At each one of the twelve collection points, three soil monoliths were sampled (Lavelle, 1988). The sampling was done using a $25 \times 25 \mathrm{~cm}$ metal quadrat, positioned at random within the central area of the plots, to avoid the effects of vegetation planted along the edges of roads, as well as possible adjacent areas of

Table 1. Levels of carbon $(\mathrm{C})$, nitrogen $(\mathrm{N})$, exchangeable calcium $(\mathrm{Ca})$, magnesium $(\mathrm{Mg})$ and $\mathrm{Ca}+\mathrm{Mg}$, $\mathrm{kaolinite}(\mathrm{k})$, gibbsite $(\mathrm{Gb})$ and kaolinite/(kaolinite + gibbsite) ratios $\left(\mathrm{R}_{\mathrm{KGb}}\right)$ at the 12 sampling points of Cerrado Oxisols under pasture.

\begin{tabular}{|c|c|c|c|c|c|c|c|c|c|c|c|}
\hline \multirow[t]{2}{*}{ Group } & \multirow[t]{2}{*}{ Point } & \multicolumn{2}{|c|}{ Coordinates } & $\mathrm{C}$ & $\mathrm{N}$ & $\mathrm{Ca}^{2+}$ & $\mathrm{Mg}^{2+}$ & $\mathrm{Ca}^{2+}+\mathrm{Mg}^{2+}$ & $\mathrm{k}$ & $\mathrm{Gb}$ & \multirow[t]{2}{*}{$\mathrm{R}_{\mathrm{KGb}}$} \\
\hline & & Latitude & Longitude & \multicolumn{2}{|c|}{----------g kg-1 --------- } & -------- & $-\mathrm{cmol}_{\mathrm{c}}$ & $g^{-1}-----------\cdot$ & \multicolumn{2}{|c|}{--------g kg k $^{-1}--------$} & \\
\hline & 1 & $15^{\circ} 36^{\prime} \mathrm{S}$ & $47^{\circ} 45^{\prime} \mathrm{W}$ & 25.05 & 1.55 & 0.46 & 0.14 & 0.60 & 472 & 340 & 0.58 \\
\hline \multirow[t]{2}{*}{ I } & 2 & $15^{\circ} 35^{\prime} \mathrm{S}$ & $48^{\circ} 06^{\prime} \mathrm{W}$ & 25.95 & 1.80 & 0.23 & 0.08 & 0.31 & 362 & 415 & 0.47 \\
\hline & 4 & $15^{\circ} 36^{\prime} \mathrm{S}$ & $47^{\circ} 42^{\prime} \mathrm{W}$ & 20.20 & 1.50 & 0.55 & 0.25 & 0.80 & 464 & 107 & 0.90 \\
\hline \multirow[t]{2}{*}{ II } & 5 & $15^{\circ} 36^{\prime} \mathrm{S}$ & $47^{\circ} 43^{\prime} \mathrm{W}$ & 14.70 & 1.25 & 0.54 & 0.24 & 0.79 & 309 & 32 & 0.81 \\
\hline & 6 & $15^{\circ} 26^{\prime} \mathrm{S}$ & $47^{\circ} 17^{\prime} \mathrm{W}$ & 12.25 & 1.10 & 0.53 & 0.16 & 0.69 & 401 & 102 & 0.80 \\
\hline \multirow[t]{3}{*}{ III } & 8 & $16^{\circ} 00^{\prime} \mathrm{S}$ & $48^{\circ} 07^{\prime} \mathrm{W}$ & 27.20 & 1.65 & 3.16 & 0.74 & 3.90 & 332 & 322 & 0.51 \\
\hline & 9 & $15^{\circ} 58^{\prime} \mathrm{S}$ & $48^{\circ} 07^{\prime} \mathrm{W}$ & 22.05 & 1.45 & 2.06 & 0.64 & 2.70 & 332 & 223 & 0.60 \\
\hline & 10 & $15^{\circ} 3^{\prime} \mathrm{S}$ & $47^{\circ} 32^{\prime} \mathrm{W}$ & 12.50 & 1.60 & 1.63 & 0.45 & 2.08 & 378 & 57 & 0.87 \\
\hline \multirow[t]{2}{*}{ IV } & 11 & $15^{\circ} 30^{\prime} \mathrm{S}$ & $48^{\circ} 08^{\prime} \mathrm{W}$ & 25.05 & 1.35 & 3.19 & 0.81 & 4.01 & 467 & 133 & 0.78 \\
\hline & 12 & $15^{\circ} 18^{\prime} \mathrm{S}$ & $47^{\circ} 14^{\prime} \mathrm{W}$ & 18.00 & 1.40 & 2.97 & 1.08 & 4.04 & 275 & 78 & 0.78 \\
\hline
\end{tabular}


native Cerrado. The soil monoliths were divided into $0-10,10-20$ and $20-30 \mathrm{~cm}$ layers to assess the vertical distribution of the macrofauna. Surface litter was also sampled. Separation of macroinvertebrates was performed manually: individuals with a body diameter greater than $2 \mathrm{~mm}$ were collected and preserved in flasks containing $70 \%$ alcohol, for subsequent counting and classification. Worms were kept in flasks containing $10 \%$ formaldehyde solution (diluted in distilled water). All individuals were counted to calculate abundance (individuals $\mathrm{m}^{-2}$ ), and identified to the level of order, at the Embrapa Cerrados laboratory of entomology.

In order to verify whether the distribution of the macrofauna correlated with the soil grouping, Goodman's nonparametric statistical test for contrasts between multinomial proportions, between and within independent populations, was applied (Goodman, 1964, 1965). This is a procedure involving contingency tables, in which the rows feature independent multinomial populations (macrofauna groups), and the columns contain different categories of observed responses (soil groups). Basically, the procedure considers the proportions (rates of occurrence) in relation to the total number of individuals in each taxonomic group and, through contrasts in multinomial proportions, the significances between the soil groups are evaluated, with a level of $5 \%$ considered significant.

\section{Results and Discussion}

The taxonomic groups (orders), in descending order of their relative density in the samples, were: Isoptera, Hymenoptera, Oligochaeta, Coleoptera (adult and larvae), Diplopoda, Chilopoda, Diptera,

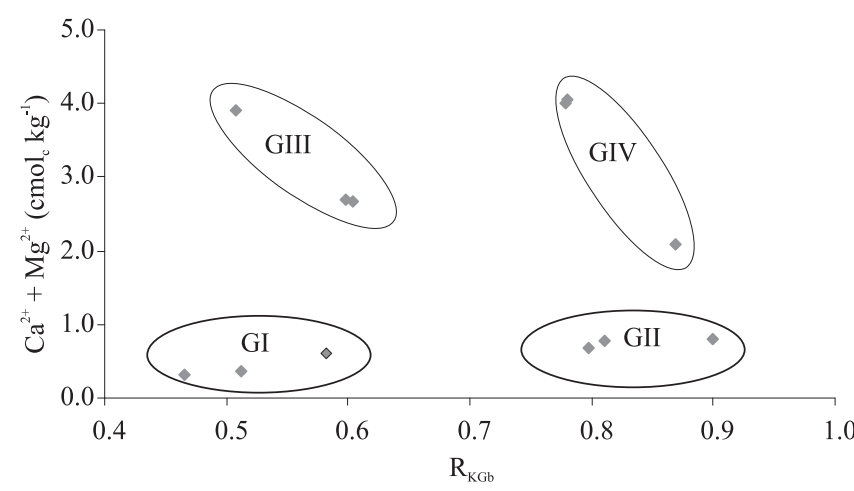

Figure 1. Grouping of sampling points in accordance with levels of exchangeable $\mathrm{Ca}^{2+}+\mathrm{Mg}^{2+}$ and kaolinite/(kaolinite + gibbsite) ratios $\left(\mathrm{R}_{\mathrm{KGb}}\right)$ in Oxisols under pasture in the Cerrado region.
Hemiptera, Lepidoptera, Homoptera, Symphyla, Araneae, Scorpiones and Pseudoscorpiones (Table 2). Chilopoda, Araneae, Scorpiones and Pseudoscorpiones are predators, which are mainly in the litter layer. Diptera, Gastropoda, Homoptera, Lepidoptera and Symphyla were grouped as "other" due to the low density observed.

The highest abundance of macrofauna was observed in GII $\left(9,263\right.$ individuals $\left.\mathrm{m}^{-2}\right)$, followed by GI $\left(2,895\right.$ individuals $\left.\mathrm{m}^{-2}\right)$, GIII $\left(2,150\right.$ individuals $\left.\mathrm{m}^{-2}\right)$ and GIV (2,075 individuals $\mathrm{m}^{-2}$ ), respectively (Table 2 ). In all plots, termites (Isoptera) accounted for the greatest number of individuals. The highest relative abundance of Isoptera was found in GII, followed by GI, in soils with low levels of exchangeable $\mathrm{Ca}+\mathrm{Mg}$. This can be explained by the fact that these termites are adapted to soils of low fertility and high aluminum saturation (Barros et al., 2002). Benito et al. (2004) also found a greater Isoptera density in soils under degraded pastures than in soils under natural vegetation and pastures managed with fertilizer. The poor litter quality of degraded pastures, as high $\mathrm{C} / \mathrm{N}$ ratio of plant tissues, as well as the low plant diversity that favors some groups becoming pests can explain the larger Isoptera density, in soils under degraded pastures (Benito et al., 2004; Constantino, 2005).

Coleoptera larvae (98-268 individuals $\mathrm{m}^{-2}$ ) and Hemiptera (260-268 individuals $\mathrm{m}^{-2}$ ) showed the highest abundance in GI and GII (Table 2). This may be related to high $\mathrm{C}$ values in these soils (Decaëns et al., 1994). However, many factors can affect these insect populations, such as the plant cover species (Santos et al., 2008), the physical impact of cultivation operations, and changes in the nature of carbon sources in the soil-plant system (Benito et al., 2004). Among the Hemiptera, the majority belonged to a species

Table 2. Mean absolute (individuals $\mathrm{m}^{-2}$ ) and relative abundance (\%) of macrofauna groups, in the soil groups ${ }^{(1)}$.

\begin{tabular}{lccrr}
\hline Taxonomic group & \multicolumn{4}{c}{ Soil group } \\
\cline { 2 - 5 } & \multicolumn{1}{c}{ GI } & GII & GIII & \multicolumn{1}{c}{ GIV } \\
\hline Isoptera & $2,100(18.45) \mathrm{b}$ & $7,031(61.76) \mathrm{a}$ & $1,096(9.63) \mathrm{c}$ & $1,157(10.16) \mathrm{c}$ \\
Hymenoptera & $249(8.16) \mathrm{d}$ & $1,865(61.13) \mathrm{a}$ & $347(11.37) \mathrm{c}$ & $590(19.34) \mathrm{b}$ \\
Coleoptera larvae & $98(20.63) \mathrm{b}$ & $52(10.95) \mathrm{c}$ & $268(56.42) \mathrm{a}$ & $57(12.00) \mathrm{c}$ \\
Coleoptera adult & $39(23.35) \mathrm{ab}$ & $64(38.32) \mathrm{a}$ & $44(26.35) \mathrm{a}$ & $20(11.98) \mathrm{b}$ \\
Oligochaeta & $16(5.28) \mathrm{c}$ & $114(37.62) \mathrm{a}$ & $57(18.81) \mathrm{b}$ & $116(38.28) \mathrm{a}$ \\
Hemiptera & $268(45.12) \mathrm{a}$ & $57(9.60) \mathrm{b}$ & $260(43.77) \mathrm{a}$ & $9(1.52) \mathrm{c}$ \\
Diplopoda & $34(61.82) \mathrm{a}$ & $0(0.00) \mathrm{c}$ & $14(25.45) \mathrm{b}$ & $7(12.73) \mathrm{b}$ \\
Predators & $16(23.53) \mathrm{a}$ & $20(29.41) \mathrm{a}$ & $14(20.59) \mathrm{a}$ & $18(26.47) \mathrm{a}$ \\
Others & $75(26.22) \mathrm{ab}$ & $60(20.98) \mathrm{b}$ & $50(17.48) \mathrm{b}$ & $101(35.31) \mathrm{a}$ \\
\hline
\end{tabular}

${ }^{(1)}$ Percentages followed by the equal letters, for the same taxonomic group, do not differ according to Goodman's test at $5 \%$ of probability. 
commonly known in Brazil as "percevejo-castanho" (Scaptocoris castanea), which normally occurs in pastures of Brachiaria sp. in the Cerrado region.

The highest densities of earthworms (Oligochaeta) were observed in GII and GIV, in soils with high values of $R_{K G b}$ (Table 2). This could be related to the occurrence of clay types, i.e. kaolinitic and gibbsitic soils in the landscape. According to Reatto et al. (2008), gibbsitic Oxisols - i.e. those of low $\mathrm{R}_{\mathrm{KGb}}-$ are mainly located on the well-drained central part of the plateau. In the lower part of the toposequence, in poorly drained position where the water table is closer to the surface, kaolinitic Oxisols or soils of high $\mathrm{R}_{\mathrm{KGb}}$ are predominant. According to Auerswald et al. (1996), soil moisture content correlates with earthworm abundance and biomass. Eventually, the kaolinitic Oxisols in the poorly drained lower parts of the toposequence, favoring a higher water retention, are a more suitable habitat for earthworms.

In all soil groups, predators represented less than $1 \%$ of the total number of individuals.

In general, it was possible to observe that the levels of exchangeable $\mathrm{Ca}+\mathrm{Mg}$ had a significant effect on the density of Isoptera, and that variation in levels of kaolinite and gibbsite helped to explain the variation in density of Oligochaeta, Coleoptera (larvae) and Hemiptera (Table 2).
These results suggest that the chemical and mineralogical characteristics of soils are considerable variables explaining abundance and distribution of macrofauna in Oxisols under pasture use in Cerrado.

For all the soil groups, the proportion of individuals found in the litter was less than $1 \%$. There were more individuals in the uppermost surface layer $(0-10 \mathrm{~cm})$ than in the lower layers, except for GIV, where the highest density of individuals was observed in the $10-20 \mathrm{~cm}$ portion (Figure 2), due to a large number of Hymenoptera found in this layer in one of the samples. The concentration of invertebrates in the upper soil layers shows the importance of surface organic material, which is most affected by the addition of organic residues and fertilizers, as observed by Aquino et al. (2008), who verified a positive correlation between density of individuals and organic material in the soil surface. Marchão (2007) also confirmed the greatest density of individuals in the $0-10 \mathrm{~cm}$ layer, in soils under pasture in Cerrado.

After Isoptera, the taxonomic groups with high abundance in the $0-10 \mathrm{~cm}$ layer were Hymenoptera and Coleoptera (larvae and adult).

The vertical distribution of Oligochaeta varied among the soil groups. In GI and GII, representing low levels of $\mathrm{Ca}+\mathrm{Mg}$, there was a predominance of
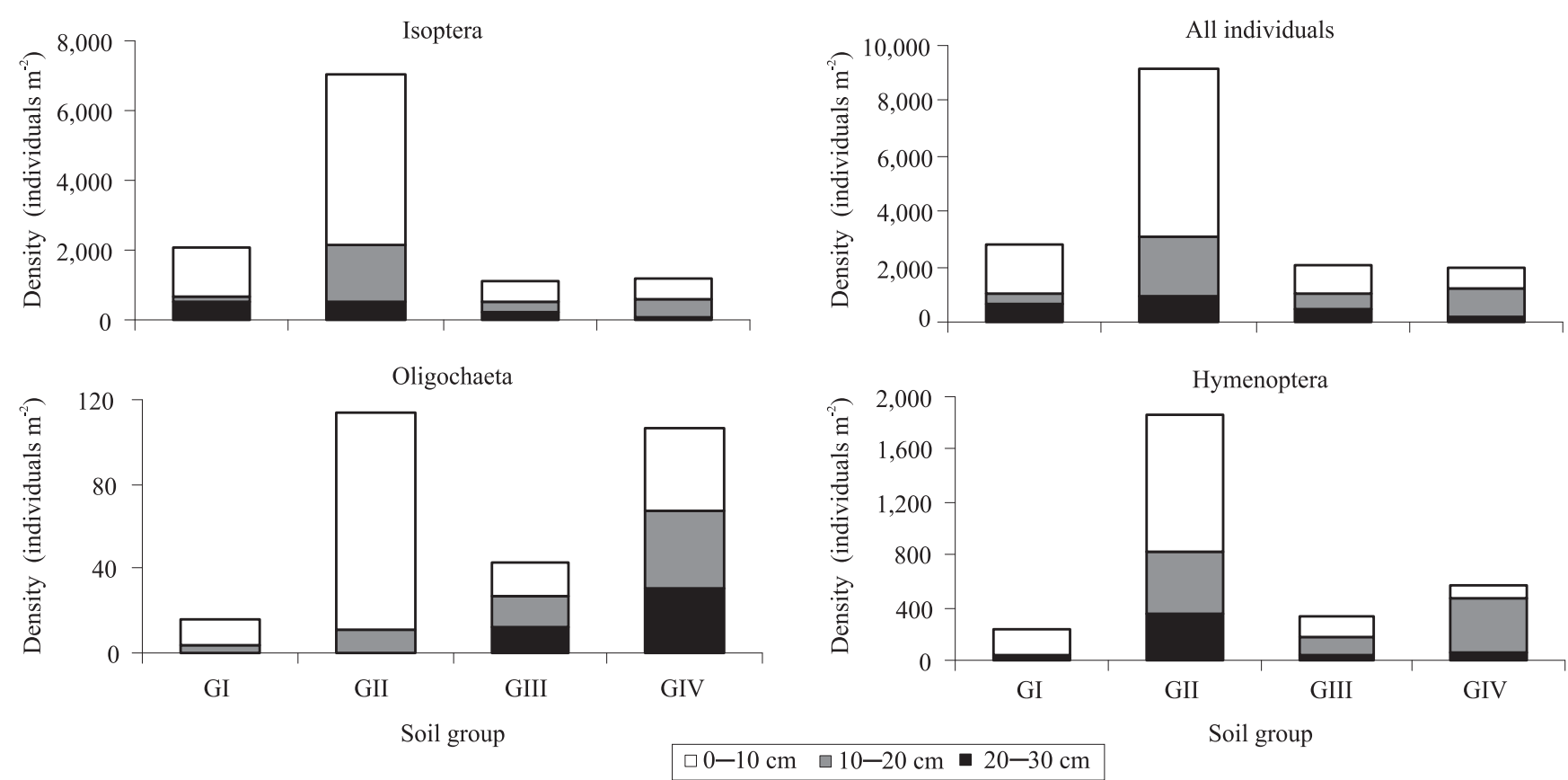

Figure 2. Vertical distribution of macrofauna (Isoptera, all individuals, Oligochaeta and Hymenoptera) in the soil groups of Oxisols under pasture, in the Cerrado region. 
these individuals in the $0-10 \mathrm{~cm}$ layer, which is in accordance with Barros et al. (2002), who found 72\% of Oligochaeta in this layer. However, for groups III and IV, from soils containing high levels of $\mathrm{Ca}+\mathrm{Mg}$, the vertical distribution of the individuals did not vary among soil layers (Figure 2).

\section{Conclusions}

1. Both mineralogy and levels of exchangeable $\mathrm{Ca}+\mathrm{Mg}$ have a significant effect on the relative and on the absolute abundance of soil macrofauna at the order level.

2. Termite abundance is correlated to soils with low levels of exchangeable $\mathrm{Ca}+\mathrm{Mg}$.

3. Earthworm abundance correlates to soils with high levels of kaolinite.

4. Abundances of Hemiptera and Coleoptera larvae correlate to gibbsitic soils with higher contents of total carbon.

\section{Acknowledgements}

To Agência Brasileira de Cooperação, Embrapa Cerrados, and Institut de Recherche pour le Développement (France), for logistical and financial support through the project "Cartografia de paisagens do bioma Cerrado e funcionamento de solos representativos"; to Professor Inês Cristina de Batista Fonseca, from the Departamento de Agronomia, of the Universidade Estadual de Londrina, for her help with the statistical analyses; to Dr. Norton Polo Benito, from Embrapa Recursos Genéticos e Biotecnologia, for his help in the macrofauna identification.

\section{References}

AQUINO, A.M. de; SILVA, R.F. da; MERCANTE, F.M.; CORREIA, M.E.F.; GUIMARÃES, M. de F.; LAVELLE, P. Invertebrate soil macrofauna under different ground cover plants in the no-till system in the Cerrado. European Journal of Soil Biology, v.44, p.191-197, 2008.

AUERSWALD, K.; WEIGAND, S.; PHILIPP, C. Influence of soil properties on the population and activity of geophagous earthworms after five years of bare fallow. Biology and Fertility of Soils, v.23, p.382-387, 1996.

BARROS, E.; PASHANASI, B.; CONSTANTINO, R.; LAVELLE, P. Effects of land-use system on the soil macrofauna in western Brazilian Amazonia. Biology and Fertility of Soils, v.35, p.338-347, 2002.
BENITO, N.P.; BROSSARD, M.; PASINI, A.; GUIMARÃES, M. de F.; BOBILLIER, B. Transformations of soil macroinvertebrate populations after native vegetation conversion to pasture cultivation (Brazilian Cerrado). European Journal of Soil Biology, v.40, p.147-154, 2004.

BLANCHART, E.; VILLENAVE, C.; VIALLATOUX, A.; BARTHÈS, B.; GIRARDIN, C.; AZONTONDE, A.; FELLER, C. Long-term effect of a legume cover crop (Mucuna pruriens var. utilis) on the communities of soil macrofauna and nematofauna, under maize cultivation, in southern Benin. European Journal of Soil Biology, v.42, p.136-144, 2006.

CLAESSEN, M.E.C. (Org.). Manual de métodos de análise de solo. $2^{\text {nd }}$ ed. Rio de Janeiro: Embrapa-CNPS, 1997. 212p. (Embrapa-CNPS. Documentos, 1).

CONSTANTINO, R. Padrões de diversidade e endemismo de térmitas no bioma Cerrado. In: SCARIOT, A.; SOUZA-SILVA, J.C.; FELFILI, J.M. (Ed.). Cerrado: ecologia, biodiversidade e conservação. Brasília: Ministério do Meio Ambiente, 2005. p.319-333.

DECAËNS, T. Degradation dynamics of surface earthworm casts in grasslands of the eastern plains of Colombia. Biology and Fertility of Soils, v.32, p.149-156, 2000.

DECAËNS, T.; LAVELLE, P.; JIMENEZ, J.J.; ESCOBAR, G.; RIPPSTEIN, G. Impact of land management on soil macrofauna in the Oriental Llanos of Colombia. European Journal of Soil Biology, v.30, p.157-168, 1994.

GOODMAN, L.A. On simultaneous confidence intervals for multinomial proportions. Technometrics, v.7, p.247-254, 1965.

GOODMAN, L.A. Simultaneous confidence intervals for contrasts among multinomial populations. Annals of Mathematical Statistics, v.35, p.716-725, 1964.

LAVELLE, P. Assessing the abundance and role of invertebrate communities in tropical soils: aims and methods. Journal of African Zoology, v.102, p.275-283, 1988.

LAVELLE, P.; DECAËNS, T.; AUBERT, M.; BAROT, S.; BLOUIN, M.; BUREAU, F.; MARGERIE, P.; MORA, P.; ROSSI, J.P. Soil invertebrates and ecosystem services. European Journal of Soil Biology, v.42, p.3-15, 2006.

LAVELLE, P.; SPAIN, A.V. Soil ecology. Dordrecht: Kluwer Academic, 2001. 654p.

MARCHÃO, R.L. Integração lavoura-pecuária num Latossolo do cerrado: impactos na física, matéria orgânica e macrofauna. 2007. 153p. Tese (Doutorado) - Universidade Federal de Goiás, Goiânia.

MELO, V.F.; SINGH，B.; SCHAEFER， C.E.G.R.; NOVAIS, R.F.; FONTES, M.P.F. Chemical and mineralogical properties of kaolinite-rich Brazilian soils. Soil Science Society of America Journal, v.65, p.1324-1333, 2001.

MOTTA, P.E.F. da; CARVALHO FILHO, A. de; KER, J.C.; PEREIRA, N.R.; CARVALHO JUNIOR, W. de; BLANCANEAUX, P. Relações solo-superfície geomórfica e evolução da paisagem em uma área do Planalto Central brasileiro. Pesquisa Agropecuária Brasileira, v.37, p.869-878, 2002. 
REATTO, A.; BRUAND, A.; MARTINS E. de S.; MULLER F.; SILVA, E.M. da; CARVALHO JUNIOR, O.A. de. Variation of the kaolinite and gibbsite content at regional and local scale in Latosols of the Brazilian Central Plateau. Comptes Rendus Geoscience, v.340, p.741-748, 2008.

REATTO,A.; MARTINS, E.S. Classes de solos em relação aos controles da paisagem do bioma Cerrado. In: SCARIOT, A.; SOUZA-SILVA, J.C.; FELFINI, J.M. (Ed.). Cerrado: ecologia, biodiversidade e conservação. Brasília: Ministério do Meio Ambiente, 2005. p.47-59.

SANO, E.E.; ROSA, R.; BRITO, J.L.S.; FERREIRA, L.G. Mapeamento semidetalhado do uso da terra do bioma Cerrado. Pesquisa Agropecuária Brasileira, v.43, p.153-156, 2008.
SANTOS, G.G.; SILVEIRA, P.M. da; MARCHÃO, R.L.; BECQUER, T.; BALBINO, L.C. Macrofauna edáfica associada a plantas de cobertura em plantio direto em um Latossolo-Vermelho do Cerrado. Pesquisa Agropecuária Brasileira, v.43, p.115-122, 2008.

SANTOS, H.G. dos; JACOMINE, P.K.T.; ANJOS, L.H.C. dos; OLIVEIRA, V.A. de; OLIVEIRA, J.B. de; COELHO, M.R.; LUMBRERAS, J.F.; CUNHA, T.J.F. (Ed.). Sistema brasileiro de classificação de solos. $2^{\text {nd }}$ ed. Rio de Janeiro: Embrapa Solos, 2006. 306p.

SILVA, R.F. da;AQUINO, A.M. de; MERCANTE, F.M.; GUIMARÃES, M. de F. Macrofauna invertebrada do solo sob diferentes sistemas de produção em Latossolo da Região do Cerrado. Pesquisa Agropecuária Brasileira, v.41, p.697-704, 2006.

Received on September 24, 2008 and accepted on July 2, 2009 